\title{
Change for the Better, or More of the Same?
}

\section{Analysing the Lithium-Ion Battery Market Through a Green Criminological Lens}

\section{Robyn Lawrence}

MSc in Transnational Crime, Justice, and Security, University of Glasgow

\begin{abstract}
This article analyses the lithium-ion Battery through a green criminological lens. It explores green criminological reasoning, particularly the framework of "ecocide," in order to frame the renewables market as an area of emergent concern for criminologists. Two case studies are analysed in pursuit of this goal: the case of coltan Mining in the Democratic Republic of the Congo; and the case of lithium extraction in the "lithium triangle" nations of Argentina, Bolivia, and Chile. This article initially examines the issue of coltan mining through a mainstream criminological lens, before moving to explore the issues from a green criminological perspective. In doing so, the advantages of the green criminological model are highlighted, and it is demonstrated that the contemporary renewables market is an area of criminological interest.
\end{abstract}

Keywords: green criminology, corporate harm, renewable energy, neocolonialism, global supply chains 


\section{Introduction}

As the effects of global warming become an everyday reality for much of the worlds' population, the imperative for a transition away from fossil fuels becomes ever clearer. Renewable energies are poised to take over from fossil fuel as the primary source of energy, and will undoubtedly present new challenges for the global community. Many renewable power solutions to the energy crisis require lithium-ion batteries, ${ }^{1}$ and the rising demand for these technologies in turn necessitates large-scale extraction of the primary resources needed to create the batteries: cobalt-tantalum (coltan) and lithium. Global demand for these minerals is thus set to soar within the next decade, with demand for lithium set to triple by $2025,{ }^{2}$ and a projected 30-fold increase in demand for coltan. ${ }^{3}$

The bulk of the world's supply of coltan lies with the Democratic Republic of the Congo (DRC), ${ }^{4}$ a mineral-rich region which has long been riven by conflict and resource exploitation. The majority of the world's lithium deposits are located in the southern Andean nations of Argentina, Bolivia, and Chile, primarily amidst Indigenous territory. ${ }^{5}$ The growth of markets for these minerals have serious ramifications for the countries at hand, as extraction operations fuel conflict and environmental degradation in the regions.

Green criminology is a theoretical perspective that has gained traction in recent years which seeks to broaden the scope of criminological inquiry to explore harms against the environment. ${ }^{6}$ The perspective adopts a harm-focussed approach to its study of environmental issues, suggesting that "crime" is an inappropriate framing for problems of this sort, as many of the most harmful ecological practices are non-criminal or legal. ${ }^{7}$ I engage with the green criminological concept of "ecocide" - a theory which explores the connections between

\footnotetext{
${ }^{1}$ Jennapher Lunde Seefeldt, "Lessons from the Lithium Triangle: Considering Policy Explanations for the Variation in Lithium Industry Development in the 'Lithium Triangle' Countries of Chile, Argentina, and Bolivia," Politics Policy, no. 48 (2020): 729.

${ }^{2}$ Seefeldt, "Lessons from the Lithium Triangle," 729.

${ }^{3}$ Patricia Alves Dias, Darina Blagoeva, Claudiu Pavel, and Nikolaos Arvanitidis, "Cobalt: DemandSupply Balances in the Transition to Electric Mobility," Publications Office of the European Union, (2018): 34.

${ }^{4}$ Dias, Blagoeva, Pavel and Arvanitidis, 35.

${ }^{5}$ Seefeldt, "Lessons from the Lithium Triangle," 729-734.

${ }^{6}$ Nigel South, "Green Criminology: Reflections, Connections, Horizons," Journal for Crime, Justice and Social Democracy 3 (2014): 6.

${ }^{7}$ South, 8-10.
} 
environmental degradation and the destruction of culture. ${ }^{8}$ Potential objections to the theory are considered and incorporated into my analysis. In doing so, I establish a theoretical framework by which we can understand and critique the harms of the resource extraction industry in renewables.

To elucidate the strengths and potential applications of these concepts, this article utilises two case studies. It begins by focusing on the extraction of coltan in the DRC, initially focusing on conventionally criminal harms, before broadening the analysis to explore the relevance of green criminology to the case. This article focuses on the supply side of the industry, in order to elucidate the significant harms, criminal and non-criminal, that occur within source countries as a result of these industries. It argues here that the scope of ecological harm, including ecocide, justifies the topic as a site of criminological inquiry, even though the harms are not strictly criminal. This article next applies this conclusion to the case of lithium-mining in the so-called "lithium triangle" countries of Argentina, Bolivia, and Chile, arguing that these cases equally merit criminological attention. Finally, it offers a framework by which "criminologically relevant" and "non-criminologically relevant" instances of resource extraction might be delineated.

\section{Green Criminology}

Green criminology is a criminological perspective that argues that criminological focus ought to include ecological issues, from the localised effects on individual environmental incidents to larger-scale problems such as climate change. ${ }^{9}$ The perspective is predominantly articulated as a harms-based approach to the criminological discipline, meaning that it regards "harm," as opposed to "crime" as the appropriate ambit of criminological investigation. "Crime," from this perspective, is seen as a socially and politically constructed concept lacking ontological reality, and thus arbitrary as a category of interest. ${ }^{10}$

\footnotetext{
${ }^{8}$ Martin Crook, Damien Short and Nigel South, "Ecocide, Genocide, Capitalism, and Colonialism: Consequences for Indigenous Peoples and Glocal Ecosystems Environments,” Theoretical Criminology no. 22 (2018).

${ }^{9}$ South, "Green Criminology," 6.

${ }^{10}$ Lynne Copson, “Beyond 'Criminology' vs. 'Zemiology': Reconciling Crime with Social Harm,” in Zemiology: Critical Criminological Perspectives, eds. Avi Boukli and Justin Kotzé (Basingstoke: Palgrave MacMillan, 2018), 36.
} 
Green criminology adopts a global analytical framework, recognising the interdependence of human and ecological systems across borders. The issues with which it concerns itself are global in scope, and focus on global actors such as corporations and states as primary perpetrators of harm. This is because the effects of ecological collapse caused by environmental degradation have global implications, from food scarcity to population displacement. ${ }^{11}$ Purported solutions to ecological problems are increasingly international in scope, with existing and proposed environmental targets and regulations coordinated by international bodies. ${ }^{12}$ Scheper-Hughes notes that, in illicit as well as licit economies, resources and capital typically flow from the Global South to the Global North, ${ }^{13}$ to which extractive industries are no exception. ${ }^{14}$ This is articulated by the "resource curse" phenomenon, wherein resource rich countries are often kept poor by their overreliance on exploitative extractive industries. ${ }^{15}$ Environmental damage is disproportionately created by the Global North, and disproportionately suffered in the Global South, throughout which countries and communities have had their resources forcibly or otherwise exploitatively depleted, damaging their ability to adequately prepare for climate-related harm. ${ }^{16}$

South thus writes of the need for green criminology to establish a robust theory of "environmental victimology." 17 Brown suggests that, in formulating such a theory, criminologists ought to identify harms from scientific data as opposed to existing

\footnotetext{
${ }^{11}$ South, "Green Criminology," 14.

${ }^{12}$ South, 14.

${ }^{13}$ For the purposes of this article, the terms "Global North" and "Global South" shall be utilised to group countries along socio-economic and political lines, as opposed to related terms such as

"developed/developing country." This is because the term captures the relations of dominance that exist between "Northern" nations over "Southern" nations more aptly than alternative terms. There are a few drawbacks to the terms. These include definitional imprecisions such as the implication that development is homogenous amongst nation states, and overgeneralisations about the material conditions in each "pole." In reality, there are "Norths" within the Global South and "South" within the Global North, and significant diversity in the socio-economic conditions of countries within either side of the dichotomy. Whilst the terms serve as effective shorthand for general dynamics which exist between regions, they are of most analytical use whilst these shortcomings are borne in mind.

${ }^{14}$ Nancy Scheper-Hughes, "Rotten Trade: Millennial Capitalism, Human Values and Global Justice in Organs Trafficking,” Journal of Human Rights 2, no. 2 (2003): 199-200.

${ }^{15}$ Jeffrey D.Sachs and Andrew Warner, "Natural Resource Abundance and Economic Growth," NBER Working Paper no. 5398 (1995): 2.

${ }^{16}$ South, "Green Criminology," 13.

${ }^{17}$ South, 13.
} 
environmental regulations, owing to the influence exerted over the latter by corporations. ${ }^{18}$ As previously stated, those in the Global South are at greater risk of environmental victimisation, but within the Global North, racial minorities are at disproportionate risk of the same. ${ }^{19}$ It is thus necessary for green criminologists to put the most vulnerable at the centre of their investigations, whilst noting that environmental damage can have significant implications for those who might traditionally be thought of as less vulnerable. ${ }^{20}$

\subsection{Ecocide}

"Ecocide" is a conceptual tool which explains the interdependency of the harms of genocide and environmental harm. ${ }^{21}$ Criminological theorising has tended to neglect the relationship between harms against the environment and harms against dispossessed populations, ${ }^{22}$ owing in part to the discipline's focus on the Global North. ${ }^{23}$ Advocates of the theory note that Indigenous scholars and activists have advanced similar concepts to that of ecocide, and of genocide, in the past, but that their knowledges have not been given due credence within the social sciences. ${ }^{24}$ The theory serves as an attempt to reconcile Indigenous knowledges with the mainstream criminological canon. Despite enjoying limited debate at the level of international jurisprudence, and adoption into the legal frameworks of certain countries, ${ }^{25}$ no international law exists which names ecocide as a crime during peacetime. ${ }^{26}$

"Ecocide" is defined by Higgins as the "extensive damage to, destruction of or loss of ecosystem(s) [...] to such an extent that peaceful enjoyment by the inhabitants of that territory

\footnotetext{
${ }^{18}$ Phil Brown, Toxic Exposures: Contested Illnesses and the Environmental Health Movement, (New York: Columbia University Press, 2007), 2.

${ }^{19}$ Michael Lynch and Paul Stretesky, "Corporate Environmental Violence and Racism," Crime, Law and Social Change 30, no. 2 (1999): 163.

${ }^{20}$ Matthew Hall, Victims of Environmental Harm: Rights, Recognition and Redress under National and International Law (London: Routledge, 2013), X.

${ }^{21}$ Crook, Short and South, "Ecocide, Genocide, Capitalism, and Colonialism."

${ }^{22}$ Lynch and Stretesky, "Corporate Environmental Violence," 173-175.

${ }^{23}$ Kerry Carrington, Russell Hogg and Máximo Sozzo, "Southern Criminology," British Journal of Criminology 56, no. 1 (2016): 1-20.

${ }^{24}$ Crook, Short and South, "Ecocide, Genocide, Capitalism, and Colonialism," 300.

${ }^{25}$ Gwendolyn J. Gordon, "Environmental Personhood,” Columbia Journal of Environmental Law 43, no. 1 (2019): 50-91. In Ecuador and Bolivia, nature, or Pachamama in the Quechua and Aymara languages of the indigenous people of the regions, has constitutionally protected legal status.

${ }^{26}$ Polly Higgins, Damien Short and Nigel South, "Protecting the Planet: A Proposal for a Law of Ecocide," Special Issue of Crime, Law, and Social Change 59, no. 3 (2013): 259. Significant and long-term damage to the natural environment during a war context is nonetheless defined as a "war crime" under the Rome Statute of the ICC.
} 
has been severely diminished." 27 This is further divided into two types of ecocide: "ascertainable" ecocide, whereby causation of environmental degradation is simply attributed to the actions of individuals or collectives; and "non-ascertainable" ecocide, cases whereby catastrophic events occur with no clear causal attribution, but which are generally attributable to, or worsened by, human action. ${ }^{28}$ The former concerns environmental harms which are localised and directly attributable to human action, such as the pollution of a water source by a corporation, whereas the latter describes the effects and harms of anthropogenic climate change.

A key facet of the concept of ecocide is its relationship with genocide. Weinstock notes that Indigenous communities have historically utilised and linked the concepts in their activism, quoting a Mapuche activist as claiming that extractivist capitalism, which had led to the impoverishment of their communities and desertification of their land, was a "planned assassination." ${ }^{29}$ Indigenous people are typically at heightened risk of the harms of ecocide, as people who are more likely to be ecologically embedded within their particular territories. ${ }^{30}$ Scholars of genocide note that the term can be deployed reductively within social scientific analysis, obscuring the nature and extent of its harms. ${ }^{31}$ As opposed to understanding genocide purely in terms of mass-extermination à la the Armenian Genocide or the Holocaust, Van Kreiken suggests a more expansive reading which views culture as the animating concept. ${ }^{32}$ According to Lemkin, the jurist behind the concept of "genocide," social collectives have essential foundations based in biological, cultural, political, and economic relations which are mutually constituted. ${ }^{33}$ For Lemkin, an attack on any of these elements could lead to the

${ }^{27}$ Damien Short, Redefining Genocide: Settler Colonialism, Social Death and Ecocide (London: Zed Books, 2016), 63.

${ }^{28}$ Short, 64.

${ }^{29}$ Quoted in Ana Weinstock, “A Decade of Social and Environmental Mobilisation against MegaMining in Chubut," in Environmental Crime in Latin America: The Theft of Nature and the Poisoning of the Land, eds. David R. Goyes, Hanneke Mol and Avi Brisman (London: Palgrave, 2017), 147-148.

${ }^{30}$ Crook, Short and South, "Ecocide, Genocide, Capitalism, and Colonialism," 305.

${ }^{31}$ Martin Shaw, What Is Genocide? (Cambridge: Polity, 2007), 48.

${ }^{32}$ Robert van Kreiken, "Rethinking Cultural Genocide: Aboriginal Child Removal and Settler-Colonial State Formation," Oceania 75, no. 2 (2004): 125-51.

${ }^{33}$ Raphael Lemkin, Axis Rule in Occupied Europe: Laws of Occupation, Analysis of Government, Proposals for Redress (Washington, DC.: Carnegie Endowment for International Peace Division of International Law, 1944). 
disintegration of the social relations of the group as a whole, constituting genocide. For many Indigenous groups, spatial embeddedness and relation to wider ecosystems can be construed as a key element of culture, implying that environmental degradation has genocidal implications for the groups. ${ }^{34}$

The exploitation of land and resources, and the subordination or dispossession of the peoples who occupy it, has economic and political roots in European settler colonialism. Early European migration to North America, for instance, had significant detrimental effects on both the Indigenous peoples of the region and the broader ecosystems in which the latter group had lived. For instance, the hunting to exhaustion of the Tatanka (the Lakota term for what is in English referred to as the "Bison") for European profit engineered the disruption of the cultural practices of the Lakota tribes whose lives and livelihoods depended on the animal. ${ }^{35}$ The concept of ecocide recognises that the crisis of climate change is not a crisis of external "environment," but rather a crisis in the relation between man-made politico-economic systems and nature, wherein the exploitation of natural resources required by the conditions of production of modern capitalism are driving the destruction of the ecosystems that support organised life on Earth. ${ }^{36}$ Agnew frames everyday participation in this process via consumerism as "everyday ecocide." 37 Resources on Earth are finite, but the logic of growth-driven capitalism requires an impossible model of endless growth, which in turn drives humanity to an unsustainable mode of life..$^{38}$ A robust green criminological perspective is thus rooted in a critical examination of the conditions of modern capitalism.

\subsection{Critiquing and Refining Green Criminology}

A potential criticism of green criminological theory is of its potential to be deployed in a "green imperialistic" manner. "Green imperialism" refers to the shifting of responsibility for the mitigation of climate collapse on to the Global South, and particularly ecologically

\footnotetext{
${ }^{34}$ Mohammed Abed, "Clarifying the Concept of Genocide," Metaphilosophy 37, no. 3-4 (2006): 326.

${ }^{35}$ Brittany Lombardo, Product of the Past: The Struggle Between the Lakota Sioux Nation and the United States Government (Salve Regina University, 2014), 3.

${ }^{36}$ Kovel in Short, "Redefining Genocide," 62.

${ }^{37}$ Robert Agnew, "The Ordinary Acts That Contribute to Ecocide: A Criminological Analysis," in The Routledge International Handbook of Green Criminology, eds. Nigel South and Avi Brisman (London: Routledge, 2013), 58-72.

38 Short, "Redefining Genocide," 188.
} 
embedded Indigenous communities. ${ }^{39}$ The argument stipulates that Global North environmental action, from the state level to the grassroots, places disproportionate burdens on Global South economies and communities as a result of their ecological positions. Lizzaralde suggests that the idea of Indigenous communities remaining ecologically embedded is rooted in a dehumanising idea of indigeneity, a modern development of the "noble savage" trope. ${ }^{40}$ Whilst it is true that Indigenous peoples have retained a deeper connection to their lands and ways of life, and have tended to live in greater concert with the wider ecosystem as a result, this does not mean that we should expect that this will go unchanged forever. ${ }^{41}$ "Culture" is not a static set of values, but rather constantly in flux; and Indigenous cultures are influenced by wider factors such as climate collapse, capitalism, and the desire to lead more comfortable lives. $^{42}$

This has two primary implications for green criminology. The first is that knowledge and perspectives originating from Indigenous communities and those in the Global South must be placed at the forefront of criminological understanding of the relevant topics. This will prevent the discipline from reifying stereotypes in its analysis, and obscuring the material interest of relevant groups in favour of an imagined conception of their interests. Heeding these perspectives will also allow green criminologists to identify harms that might have been otherwise overlooked, and treat them with the severity they warrant. The second major implication is that the discipline must maintain a robust and critical understanding of the power relations between the Global North and Global South, and of the stratification of power within societies in these regions. That is to say that the discipline ought to focus on how international systems of capitalism and neo-colonial exploitation shape the actions of comparatively weaker nations and groups, as opposed to locating its focus solely on the actions of comparatively weaker states and those within them. In doing so, the discipline can avoid recreating, or advocating, the entrenchment of harmful power relations under the status quo.

\footnotetext{
${ }^{39}$ Manuel Lizzaralde, "Green Imperialism: Indigenous People and Conservation of Natural Environments," in Our Backyard: A Quest for Environmental Justice, eds. Diana Whitelaw and Gerald Visgilio (Oxford: Rowman and Littlefield, 2003), 39.

${ }^{40}$ Lizzaralde, 39.

${ }^{41}$ Lizzaralde, 40.

${ }^{42}$ Lizzaralde, 40.
} 


\section{The Global Renewables Sector - A Case Study}

This section explores the sourcing of resources for the global market in lithium-ion batteries as a case study for the theoretical perspectives outlined above. I focus here on two primary resources which are involved in the supply chain from lithium-ion batteries and two contexts from which they are, respectively, sourced. These are cobalt, from coltan mines in the DRC, and lithium, from the so-called "lithium triangle" nations of Argentina, Bolivia, and Chile. I engage with coltan mining in the DRC as a topic of consideration for mainstream criminological approaches, before exploring the case through a green criminological lens. I show that the scope and scale of the environmental harms that occur as a result of coltan mining warrant criminological attention. I subsequently apply this conclusion to lithium mining in the "lithium triangle," arguing that this supply chain ought to be scrutinised via criminological theorising and providing a framework under which to do so.

\subsection{Coltan Mining in the Democratic Republic of the Congo}

Coltan contains cobalt, a key component of the transistors within lithium-ion batteries. The DRC accounted for approximately $50 \%$ of cobalt production worldwide in $2018 .{ }^{43}$ This section explores the coltan mining sector within the DRC through a criminological lens. First outlining how the topic fits within a mainstream criminological focus, and secondly by exploring the topic through a green criminological lens. I argue that we ought to adopt the latter perspective when engaging with the topic, as failing to do so obscures some of the greatest potential harms from criminological enquiry.

Two primary aspects of coltan mining in the DRC are of traditional criminological interest: the ownership of mines by illicit organisations; and the use of exploitative and informal labour in mines. The DRC has been affected by violent conflict for much of its short history, being the site of the most deadly conflict since World War Two in the form of the second Congo War, and suffering contemporarily from significant militia conflict.$^{44}$ Eichstaedt notes that the opportunities for economic gain afforded by coltan were a proximate cause of the conflicts that

\footnotetext{
${ }^{43}$ Patricia Alves Dias, Darina Blagoeva, Claudiu Pavel and Nikolaos Arvanitidis, Cobalt: DemandSupply Balances in the Transition to Electric Mobility (Luxembourg: Publications Office of the European Union, 2018), 35.

${ }^{44}$ Peter Eichstaedt, Consuming the Congo: War and Conflict Minerals in the World's Deadliest Place (Chicago: Chicago Review Press, 2011), 113.
} 
ultimately became the first and second Congo wars. ${ }^{45}$ Moreover, contemporary conflict within the DRC is both motivated and sustained by access to mining operations. Motivated insofar as militias instigate conflict for control of the mines, which provide a valuable source of revenue, and sustained insofar as access to the mines provides militias with the ability to continue fighting for longer periods. ${ }^{46}$ This has three major implications for criminology. Firstly, international demand for coltan directly funds criminal organisations, by virtue of the limited supply of the mineral and inadequate source verification. ${ }^{47}$ Secondly, this process further entrenches conflict and instability within the DRC, and deprives its government of revenue from these extractive operations. Thirdly, it creates a reliance on exploitative forms of labour within mines - thought to affect $30 \%$ of annual coltan supply ${ }^{48}$ - which are disproportionately likely to expose workers to risks and hazards, without sufficient remuneration.

The above elements of the coltan extraction process involve elements which clearly contravene criminal law. Utilising green criminological theories we can broaden our investigation to examine non-criminal elements of the process which are nonetheless harmful. The environmental damage caused by coltan mining, for instance, is not clearly an issue of criminal law, but engenders significant harm for those affected. The Congo rainforest is particularly important as a carbon sink and a site of biodiversity, functions which are both significantly undermined by the deforestation caused as a result of coltan mining. ${ }^{49}$ In this way mining operations threaten the wider environment, with global repercussions.

Despite these global implications, the most immediate harms are borne by the local populations. Those working in the informal mining economy are exposed to particulate matter as a result of insufficient health and safety procedures within mines, and resultantly suffer

\footnotetext{
${ }^{45}$ Eichstaedt, 112.

${ }^{46}$ Justin M. Conrad, Kevin T. Greene, James I. Walsh and Beth E. Whitaker, "Rebel Natural Resource Exploitation and Conflict Duration," Journal of Conflict Resolution 63, no. 3 (2018): 596.

${ }^{47}$ Henry Sanderson, "Congo, Child Labour and Your Electric Car," Financial Times, July 7, 2019, https://www.ft.com/content/c6909812-9ce4-11e9-9c06-a4640c9feebb.

${ }^{48}$ Sanderson.

${ }^{49}$ Julie Loisel, Angela V. Gallego-Sala and Matt J. Amesbury, "Expert Assessment of Future Vulnerability of the Global Peatland Carbon Sink," Nature Climate Change, no. 11 (2021): 70-77.
} 
higher rates of respiratory dysfunction. ${ }^{50}$ Additionally, water sources in communities surrounding mining operations are likely to be contaminated by heavy metals, rendering them undrinkable, such as in the Edege-Mbeki mining district. ${ }^{51}$ The traditional lands of the Mbuti, Baka, and Batwa tribes are significantly threatened by the encroachment of industrial operations and deforestation. These Indigenous groups are traditionally nomadic, but have increasingly been forced to abandon their traditional ways of life as land enclosure limits their movement. ${ }^{52}$ This has created an untenable position for these communities, placing many into extreme poverty, and even bonded labour. ${ }^{53}$ Higgins would suggest that the treatment of these Indigenous peoples constitutes ascertainable ecocide, as their lands and culture are stripped away. ${ }^{54}$ This can be seen as an extension of the imperialistic power relations between the region and European powers historically. Extractive capitalism and resource exploitation fueled the colonial domination of the Congo, and the modern demand for resources drives its continued exploitation and the destruction of its ecological systems.

Green criminological theorising suggests that we view these strictly non-criminal harms as a matter of criminological interest, equal to those harms which have been traditionally deemed criminal. This is a position justified by two primary considerations: the arbitrariness behind the delineation of "crimes" from "harms" by states; and the significance of the harms occasioned by non-criminal actions. In the case of environmental damages, capitalist states have vested interests in situating environmental harm outside the remit of crime as they are reliant upon resource exploitation to grow their economies. "Crime" in this instance, is not an appropriate analytical concept for guiding our analytical focus and perspective. On the other hand, the harm caused by environmental damage is significant, both to those whom it directly affects, and those whom it affects more distantly.

\footnotetext{
${ }^{50}$ Ngombe Leon-Kabamba, Nlandu R. Ngatu, Sakatolo J.B. Kakomaet al., "Respiratory Health of Dust-Exposed Congolese Coltan Miners," International Archives of Occupational and Environmental Health 91 (2018): 859.

${ }^{51}$ Mohammed E. Isah, Nuhu A. Abdulmumin and Paul D. Elaoyi, "Effects of Columbite/Tantalite (COLTAN) Mining Activities on Water Quality in Edege-Mbeki Mining District of Nasarawa State, North Central Nigeria," Bulletin of the National Resource Centre 43, no. 179 (2019): 4-6.

52 "Republic of Congo," IWGIA, October 31, 2011. https://www.iwgia.org/en/republic-of-congo.

${ }^{53}$ IWGIA.

${ }^{54}$ Short, "Redefining Genocide."
} 


\subsection{Lithium Mining in the "Lithium Triangle"}

This section engages with a second supply chain of importance to the global renewables market: lithium mining in the so-called "lithium triangle" nations of Argentina, Bolivia, and Chile. These nations contain, cumulatively, approximately 47 million metric tonnes of lithium, the bulk of the world supply. ${ }^{55}$ Each country has a substantially different legal-regulatory environment surrounding the mining of lithium, and has developed their capacities to differing extents. The lithium deposits are primarily located in the countries' salt flats, which are disproportionately areas of Indigenous settlement. ${ }^{56}$ This section explores the extraction of lithium in this region through a green criminological lens, arguing that although the harms explored are not explicitly illegal in the majority of cases, they ought to be understood as part of a broader system of harms which renders them as topics of criminological enquiry.

Utilising Higgins' framework, it is possible to understand the lithium extraction industry through the lens of ecocide. ${ }^{57}$ The process of lithium extraction in the "lithium triangle" requires a significant portion of the water from the surrounding regions $-65 \%$ in the Salar de Atacama $^{58}$ - which has, or is likely to lead to, desertification of the surrounding regions. The deprivation of water from these communities is likely to have a significant deleterious effect on the groups' abilities to continue their ways of life, including traditional farming practices and ritual. ${ }^{59}$ The result is likely to be that the potential of the region to support life will be significantly diminished, as per Higgins' definition of ecocide. ${ }^{60}$ Some communities within the region have identified this process of environmental degradation with a concerted effort to remove their land rights, and destroy their belief systems. Given this, and as the causal chain is easily attributable to companies engaging in lithium mining operations, this process would be appropriately described as "ascertainable" ecocide. ${ }^{61}$

\footnotetext{
55 Seefeldt, "Lessons from the Lithium Triangle," 730.

56 Seefeldt, 734.

57 Short, "Redefining Genocide."

58 "Developing Countries Pay Environmental Cost of Electric Car Batteries," UNCTAD, July 22, 2020, https://unctad.org/news/developing-countries-pay-environmental-cost-electric-car-batteries.

${ }^{59}$ Sally Babidge, and Paola Bolados, "Neoextractivism and Indigenous Water Ritual in Salar de Atacama, Chile," Latin American Perspectives 45, no. 5 (2018): 170-85.

60 Short, "Redefining Genocide," 63.

${ }^{61}$ Short, 64.
} 
The process of lithium extraction can be understood as an aspect of the capitalist "treadmill" of production, ${ }^{62}$ wherein the drive for endless growth fuels the destruction of natural systems. Renewable energies which typically require lithium-ion batteries, are positioned as environmentally friendly alternatives to fossil fuels. They are not, however, a radical departure from growth-driven capitalist modes of production, in and of themselves. Personal electric vehicles, for instance, are a significant driver of demand for lithium-ion batteries, and are not so much a rejection of capitalist-consumerist modes of production so much as they represent an adaptation of these modes to a different paradigm.

\subsection{Implications of the Case Studies for Green Criminology}

Contemporary extractive industries in lithium and coltan have significant environmental, and ecocidal, ramifications. By virtue of this fact, it is appropriate that they should be considered as within the ambit of green criminology. Nonetheless, it is incumbent upon green criminologists to be reflexive in their suggestions of solutions to this problem. Green criminology has been critiqued for its focus on regulatory frameworks as a solution to the problems presented by environmental harm. ${ }^{63}$ According to these critiques, a focus on regulatory systems can lead to the re-establishment of the logics of "crime" and "criminality" that the predominantly harms-based green criminological approach may otherwise eschew. If issues of environmental harm come to be defined in this way, the field runs the risk of legitimising some types of environmental harm via their exclusion from regulatory frameworks, whilst punishing other forms ${ }^{64}$ This is particularly problematic given Brown's observation that corporations exercise significant influence over regulatory processes. ${ }^{65} \mathrm{~A}$ robust green criminological perspective must maintain a reflexively critical stance towards regulatory and criminal justice systems, in order to avoid reifying their assumptions and logics in its analyses.

\footnotetext{
${ }^{62}$ Crook, Short, and South, "Ecocide, Genocide, Capitalism, and Colonialism," 307.

${ }^{63}$ Mark Halsey, “Against 'Green' Criminology,” The British Journal of Criminology, 44, no. 6 (2004): $833-853$.

${ }^{64}$ Halsey, 835-837.

${ }^{65}$ Brown, Toxic Exposures, 2.
} 
It is particularly crucial that the needs and wishes of Indigenous peoples be foregrounded in such an analysis. For instance, many Indigenous groups in the Andean region are not opposed to lithium mining per se, and indeed many welcome it, though they reject the operations which are currently being carried out. ${ }^{66}$ The Bolivian government under the current MAS ("Movement for Socialism") administration has announced its intentions to grow the nation's economy utilising their lithium reserves, ${ }^{67}$ whilst commanding a vast base of support amongst Indigenous Bolivians. ${ }^{68}$ Ignoring these facts would be to participate in "green imperialist" analysis which assumes a rigidity in Indigenous and Global South culture and values, and advocates against development opportunities for poor economies whilst inadequately problematising the processes of global capitalism. This is to say nothing of the necessity of developing sustainable alternatives to fossil fuels, which pose a wide-reaching environmental threat. A green criminological approach which focuses on regulatory frameworks is liable to produce a green imperialist system of environmental governance, in which countries of the Global South are denied development opportunities, whilst continuing to exist under the system of global capitalism.

It remains likely that regulatory systems will play a role in addressing environmental harm in the future, but it is imperative that criminologists are critical in their analysis of how these frameworks are deployed, and whose interests they serve. Industries that source the materials for renewable energy ought to be regarded as of criminological interest insofar as they cause significant harm to communities, especially where they do so without the informed consent of communities, sufficient remuneration, or reparation. However, a focus upon regulatory or legal practices, or frameworks such as Agnew's "everyday ecocide" ${ }^{99}$ which individualise systemic issues, is ultimately misplaced. Green criminology must take the additional step of critiquing

\footnotetext{
${ }^{66}$ Eniko Horvath and Amanda R. Medina, "Indigenous People’s Livelihoods at Risk in Scramble for Lithium, the New White Gold,” Reuters, April 9, 2019, https://www.reutersevents.com/sustainability/indigenous-peoples-livelihoods-risk-scramble-lithium-new-whitegold.

${ }^{67}$ Javiera Barandiarán, "Lithium and Development Imaginaries in Chile, Argentina and Bolivia," World Development 113 (2019): 381.

${ }^{68}$ Nancy Postero, "Morales's MAS Government: Building Indigenous Popular Hegemony in Bolivia," Latin American Perspectives 37, no. 3 (2010): 23.

69 Agnew, "The Ordinary Acts that Contribute to Ecocide."
} 
the growth imperative of modern global capitalism, focusing on the root causes of the problem as opposed to tackling its symptoms. Such a focus would liberate the discipline from the false dichotomy of green imperialism on the one hand, and neocolonialism, environmental degradation and ecocide on the other.

\section{Conclusion}

The global market in renewables - typified by the lithium-ion battery market - ought to be subjected to criminological inquiry on the basis of the significant harms inherent to the resource extraction processes. This article has demonstrated, with reference to green criminological theory and the concept of "ecocide," that contemporary coltan extraction in the DRC and lithium extraction in the "lithium triangle" is of significant harm to the regions and their Indigenous populations. Drawing upon existing literature, this article has suggested a framework by which criminologists might approach extractive industry through a green criminological perspective. In doing so, it has addressed the limitations of a regulatory approach to issues of environmental harm and proposed that the discipline maintain a critical harm-based focus.

\section{Bibliography}

Abed, Mohammed. "Clarifying the Concept of Genocide." Metaphilosophy 37, no. 3-4 (2006): 308-330. https://doi.org/10.1111/j.1467-9973.2006.00443.x

Agnew, Robert. "The Ordinary Acts That Contribute to Ecocide: A Criminological Analysis" in The Routledge International Handbook of Green Criminology, edited by Nigel South and Avi Brisman, 58-72. London: Routledge, 2013.

Alves Dias, Patricia, Darina Blagoeva, Claudiu Pavel and Nikolaos Arvanitidis. "Cobalt: Demand-Supply Balances in the Transition to Electric Mobility." Publications Office of the European Union, 2018. https://doi.org/10.2760/97710, JRC112285.

Babidge, Sally and Paola Bolados. "Neoextractivism and Indigenous Water Ritual in Salar de Atacama, Chile." Latin American Perspectives 45, no. 5 (2018): 170-185. https://doi.org/10.1177/0094582X18782673.

Barandiará, Javiera. "Lithium and Development Imaginaries in Chile, Argentina and Bolivia." World Development 113 (2019): 381-391. https://doi.org/10.1016/j.worlddev.2018.09.019. 
Brown, Phil. Toxic Exposures: Contested Illnesses and the Environmental Health Movement. New York: Columbia University Press, 2007.

Carrington, Kerry, Russell Hogg and Máximo Sozzo. "Southern Criminology.” British Journal of Criminology 56, no. 1 (2016): 1-20. https://doi.org/10.1093/bjc/azv083.

Conrad, Justin M., Kevin T. Greene, James I. Walsh and Beth E. Whitaker. "Rebel Natural Resource Exploitation and Conflict Duration." Journal of Conflict Resolution 63, no. 3 (2018): 591-616. https://doi.org/10.1177/0022002718755853.

Copson, Lynne. “Beyond 'Criminology' vs. 'Zemiology': Reconciling Crime with Social Harm" in Zemiology: Critical Criminological Perspectives. edited by Avi Boukli and Justin Kotzé, 34-53. Basingstoke: Palgrave MacMillan, 2018.

Crook, Martin, Damien Short and Nigel South. "Ecocide, Genocide, Capitalism, and Colonialism: Consequences for Indigenous Peoples and Glocal Ecosystems Environments." Theoretical Criminology 22 (2018): 298-317. https://doi.org/10.1177/1362480618787176.

Dickson, Ellsworth. "South America's Perspective - The Lithium Triangle." Resource World. 2017. https://resourceworld.com/lithium-triangle/.

Eichstaedt, Peter. Consuming the Congo: War and Conflict Minerals in the World's Deadliest Place. Chicago: Chicago Review Press, 2011.

Gordon, Gwendolyn J. "Environmental Personhood." Columbia Journal of Environmental Law 43, no. 1 (2019): 50-91. https://doi.org/10.7916/cjel.v43i1.3742.

Hall, Matthew. Victims of Environmental Harm: Rights, Recognition and Redress under National and International Law. London: Routledge, 2013.

Halsey, Mark. “Against 'Green' Criminology.” The British Journal of Criminology 44, no. 6 (2004): 833-853. https://doi.org/10.1093/bjc/azh068

Higgins, Polly, Damien Short and Nigel South. "Protecting the Planet: A Proposal for a Law of Ecocide." Special Issue of Crime, Law, and Social Change 59, no. 3 (2013): 251266. https://doi.org./10.1007/s10611-013-9413-6

Horvath, Eniko and Amanda Medina. "Indigenous People's Livelihoods at Risk in Scramble for Lithium, the New White Gold." Reuters. April 9, 2019. https://www.reutersevents.com/sustainability/indigenous-peoples-livelihoods-riskscramble-lithium-new-white-gold

ICE Coalition. "The Case for an International Court for the Environment." ICE Coalition. June 2011.

Isah, Mohammed E., Nuhu A. Abdulmumin and Paul D. Elaoyi. "Effects of Columbite/Tantalite (COLTAN) Mining Activities on Water Quality in Edege-Mbeki Mining District of Nasarawa State, North Central Nigeria." Bulletin of the National Resource Centre 43, no. 179 (2019) https://doi.org/10.1186/s42269-019-0237-0

IWGIA. "Republic of Congo.” IWGIA. October 31, 2011. https://www.iwgia.org/en/republicof-congo.html 
Lemkin, Raphael. Axis Rule in Occupied Europe: Laws of Occupation, Analysis of Government, Proposals for Redress. Washington, DC.: Carnegie Endowment for International Peace Division of International Law, 1944.

Leon-Kabamba, Ngombe, Nlandu R. Ngatu, Sakatolo J.B. Kakomaet al. "Respiratory Health of Dust-Exposed Congolese Coltan Miners." International Archives of Occupational and Environmental Health 91 (2018): 859-864. https://doi.org/10.1007/s00420-0181329-0

Lizzaralde, Manuel. "Green Imperialism: Indigenous People and Conservation of Natural Environments." In Our Backyard: A Quest for Environmental Justice. edited by Diana Whitelaw and Gerald Visgioio, 39-52. Oxford: Rowman and Littlefield, 2003.

Loisel, Julie, Angela V. Gallego-Sala and Matt J. Amesbury. "Expert Assessment of Future Vulnerability of the Global Peatland Carbon Sink." Nature Climate Change. 11 (2021): 70-77. https://doi.org/10.1038/s41558-020-00944-0

Lombardo, Brittany. Product of the Past: The Struggle Between the Lakota Sioux Nation and the United States Government. Salve Regina University, 2014.

Lynch, Michael and Paul Stretesky. "Corporate Environmental Violence and Racism." Crime, Law and Social Change 30, no. 2 (1999): 163-184. https://doi.org/10.1023/A:1008393401769

Lynch, Michael and Paul Stretesky. Exploring Green Criminology: Towards a Green Criminological Revolution. Farnham: Ashgate, 2014.

Postero, Nancy. "Morales's MAS Government: Building Indigenous Popular Hegemony in Bolivia." Latin American Perspectives 37, no. 3 (2010): 18-34. https://doi.org/10.1177/0094582X10364031

Sachs, Jeffrey and Andrew Warner. "Natural Resource Abundance and Economic Growth." NBER Working Paper 5398 (1995). DOI:10.3386/w5398

Sanderson, Henry. "Congo, Child Labour and Your Electric Car.” Financial Times, 2019. https://www.ft.com/content/c6909812-9ce4-11e9-9c06-a4640c9feebb

Scheper-Hughes, Nancy. "Rotten Trade: Millennial Capitalism, Human Values and Global Justice in Organs Trafficking." Journal of Human Rights 2, no. 2 (2003): 197-226. https://doi.org/10.1080/1475483032000078189

Seefeldt, Jennapher. "Lessons from the Lithium Triangle: Considering Policy Explanations for the Variation in Lithium Industry Development in the 'Lithium Triangle' Countries of Chile, Argentina, and Bolivia." Politics Policy 48 (2020): 727-65. https://doi.org/10.1111/polp.12365

Shaw, Martin. What Is Genocide? Cambridge: Polity, 2007.

Short, Damien. Redefining Genocide: Settler Colonialism, Social Death and Ecocide. London: Zed Books, 2016.

South, Nigel. "Green Criminology: Reflections, Connections, Horizons." Journal for Crime, Justice and Social Democracy 3 (2014): 6-21. https://doi.org/10.5204/ijcjsd.v3i2.172. 
UNCTAD. "Developing Countries Pay Environmental Cost of Electric Car Batteries." UNCTAD. July 22, 2020. https://unctad.org/news/developing-countries-payenvironmental-cost-electric-car-batteries

Van Kreiken, Robert. "Rethinking Cultural Genocide: Aboriginal Child Removal and SettlerColonial State Formation." Oceania 75, no. 2 (2004): 125-151. https://doi.org/10.1002/j.1834-4461.2004.tb02873.x

Weinstock, Ana. "A Decade of Social and Environmental Mobilisation against Mega-Mining in Chubut" In Environmental Crime in Latin America: The Theft of Nature and the Poisoning of the Land. edited by David R. Goyes, Hanneke Mol and Avi Brisman, 141-162. London: Palgrave, 2017. 